\title{
Studies on the thermal stabilization for Polyvinyl chloride by some metal stearates
}

\author{
*Haider A. Mahdi \\ ${ }^{* *}$ Mouayed Y. Kadhum \\ *Amal H. Anathiel \\ ${ }^{* *}$ Department of Chemistry - College of Education - University of Basra \\ *Department of Chemistry - College of Science - University of Thi-Qar
}

\begin{abstract}
In this study, preparation of some metal stearates derived from stearic acid with metals ; Iron, Cobalt, Nickel, Copper and Zinc . They were used as thermal stabilizers for Polyvinyl chloride. These metal stearates were identified by elemental analysis and infrared spectroscopy.I.R, spectroscopy within the rang $1500-1900 \mathrm{~cm}^{-1}$ was used to study the thermal stability for PVC containing prepared metal stearates, and that depending on thin films technique. The variations in the absorption bands intensity of the groups $\mathrm{C}=\mathrm{O}, \mathrm{C}=\mathrm{C}$, $\mathrm{COO}^{-}$at $195^{\circ} \mathrm{C}$ were studied at different times $(15,30,45,60 \mathrm{~min})$ from thermal stress. These variations resulted from the rule of the metal stearates in the stabilizing of polymer . U.V-V.S spectroscopy was used to study the thermal degradation of unstabilized PVC and the reprecipitated PVC from the stabilizers .This study was carried out by the investigation of the polymer resulted from the evolving of $\mathrm{HCl}$ from the polymer chain at $275 \mathrm{~nm}$ and $385 \mathrm{~nm}$ corresponding to three and seven conjugated double bonds respectively .The results were indicated that metal stearates and their synergistic mixtures have the ability to stabilize PVC by decreasing the conjugated double bonds in the polymer .

The thermal stability of the unstabilized PVC and PVC containing different metal stearates was investigation by thermogravimetric analysis (TGA). Many functions were calculated such as the decomposition temperature , rate of decomposition ,activation energy ,char content , and percentage of $\mathrm{HCl}$ evolving from the polymer chain. The results indicated that metal stearates was increasing the thermal stability for PVC. TGA was also used to evaluate the synergistic effect for some mixtures of the prepared metal stearates (Zinc stearate with stearates of the Nickel ,Cobalt, Copper, Iron ), and it was found that these mixtures have high stabilizing ability for the PVC .
\end{abstract}




\section{Introduction}

PVC is commonly used as thermoplastic because of its wide variability of properties allowing its application in rigid and soft products. However, PVC has very poor thermal stability ${ }^{(1)}$. The major chain degradation occurs by the elimination of $\mathrm{HCl}$ and simultaneous formation of conjugated double bond leading to a colour change and also causes the deteriorations of physical, chemical and electrical properties

Dehydrochlorination can occur at only moderately elevated temperatures ( about $100{ }^{\circ} \mathrm{C}$ ). It is catalyzed by the $\mathrm{HCl}$ evolved ( autocatalysis ), and can also be promoted or initiated by other strong acids . The general mechanism of degradation of PVC is shown below ${ }^{(2,3)}$ :<smiles>CC=CC(Cl)CC(Cl)CC(Cl)CCCC=CC=CC(Cl)CC(Cl)CCCC=CC=CC=CC(Cl)CC</smiles>

Thermal stability of PVC can be improved using various types of stabilizers which can quench the $\mathrm{HCl}$ produced such as metal carboxylates . It is generally accepted that thermal degradation of PVC can be blocked or retarded by metal carboxylates which must perform at least two basic functions ; substitute stable group for labile chlorine atoms in PVC chains ( allylic or tertiary chlorine atom ) and react with $\mathrm{HCl}$ generated by the degradation process ${ }^{(4,5)}$. The most important stabilizers of PVC are different metal caboxylates like $\mathrm{Pb}$ - , Cd- , Ba- ,Ca-, and Zn- carboxylates and some mono alkyl tin compounds . while thermal stabilizers based on tin and lead are most effective in some cases, they are not used any more since they are poisonous and are substituted by $\mathrm{Ca}-\mathrm{Zn}$-stabilizer which are nontoxic ${ }^{(1,6)}$. Many researchers have tried to study or explain the synergism of mixtures in the thermal stabilization of $\mathrm{PVC}^{(7-9)}$.
In this thermal stabilizers was prepared derived from stearic acid with $\mathrm{Fe}, \mathrm{Co}, \mathrm{Ni}, \mathrm{Cu}$, and $\mathrm{Zn}$ metals, also the role of these metal stearates and their synergistic mixtures on the thermal stabilization of PVC by infrared and ultraviolet visible spectrophotometers as well as thermogravimetric analysis was studied.

\section{Procedures}

\section{Preparation of metal stearates}

(4 g , 0.014 mole) from stearic acid was dissolved in $100 \mathrm{~cm}^{-3}$ of alkaline water ( $0.14 \mathrm{M})$ of potassium hydroxide . The mixture was heated and stirred. Potassium salt of stearic acid was formed, after that $100 \mathrm{~cm}^{-3}$ of solution from cobalt salt $(0.07 \mathrm{M})$ was added. The formed mixture was also stirred and it was observed formation of precipitated cobalt stearate, filtered and washed with water then with methanol and dried until constant weight was obtained. All the metal_stearates has been prepared as in above away ${ }^{(10,11)}$.

$$
\begin{aligned}
& \mathrm{CH}_{3}\left(\mathrm{CH}_{2}\right)_{16} \mathrm{COOH}+\mathrm{KOH} \longrightarrow \mathrm{CH}_{3}\left(\mathrm{CH}_{2}\right)_{16} \mathrm{COOK}+\mathrm{H}_{2} \mathrm{O} \\
& \mathrm{n} \mathrm{CH}_{3}\left(\mathrm{CH}_{2}\right)_{16} \mathrm{COOK}+\mathrm{MCl}_{\mathrm{n}} \longrightarrow \mathrm{M}\left(\mathrm{CH}_{3}\left(\mathrm{CH}_{2}\right)_{16} \mathrm{COO}\right)_{2}+\mathrm{nKCl} \\
& \text { Where : } \mathrm{M}=\mathrm{Co}, \mathrm{Ni}, \mathrm{Cu}, \mathrm{Zn}(\mathrm{n}=2) \text { or } \mathrm{Fe}(\mathrm{n}=3)
\end{aligned}
$$




\section{Preparation of stabilized PVC} samples

The stabilized PVC samples were prepared by mixing prepared stabilizers with (4\%w/w ) PVC. In order to study of synergistic effect of these stabilizers, $0.2 \mathrm{~g}$ each of two metal stearates were mixed with $10 \mathrm{~g}$ of PVC by grinding the require amount in mortar for 15 minutes ${ }^{(11,12)}$.

IR with range $\left(1500-1900 \mathrm{~cm}^{-1}\right)$ were recorded for stabilized PVC films ( thickness $=0.17 \mathrm{~mm}$ ) at different periods of exposure to thermal stress at $195{ }^{\circ} \mathrm{C}$. Furthermore, ultraviolet visible spectra at $275 \mathrm{~nm}$ and $385 \mathrm{~nm}$ were used to study the thermal degradation of unstabilized PVC and reprecipitated PVC from stabilizers (13)

Thermogravimetric analysis technique was also evaluated for stabilized PVC samples with heating rate of $20{ }^{\circ} \mathrm{C} / \mathrm{min}$ in nitrogen atmosphere ( gas flow rate equal $30 \mathrm{ml} / \mathrm{min}$ ) .

\section{Results and discussion \\ Identification of metal stearates}

Table (1) is illustrated some physical properties of prepared metal stearates . The metal stearates have a wide range of melting points, and that seem to have liquid crystalline properties ${ }^{(14,15)}$, The metal stearates were identified by elemental analysis, and the results show that the practical percentage of carbon and hydrogen are equivalent to the theoretical values .

In addition, These metal stearates were also identified by infrared spectra as shown in table (2) and figure (1-6)

Table (1) physical properties and elemental analysis for prepared metal stearates

\begin{tabular}{|c|c|c|c|c|c|c|}
\hline Compound & Formula & $\begin{array}{c}\mathrm{C} \% \\
\text { Theoritical } \\
\text { Practical }\end{array}$ & $\begin{array}{c}\mathbf{H} \% \\
\text { Theoritical } \\
\text { Practical }\end{array}$ & $\begin{array}{c}\text { Melting } \\
\text { point }\end{array}$ & Color & $\begin{array}{l}\text { Yeild } \\
\text { (\%) }\end{array}$ \\
\hline $\mathrm{Fe}$ Stearate & {$\left[\mathrm{Fe}\left(\mathrm{CH}_{3}\left(\mathrm{CH}_{2}\right)_{1}, \mathrm{COO}\right)_{3}\right] \mathrm{H}_{2} \mathrm{O}$} & $\begin{array}{l}70.16 \\
69.98\end{array}$ & $\begin{array}{l}11.66 \\
10.93\end{array}$ & $99-106$ & $\begin{array}{l}\text { Brown } \\
\text { powder }\end{array}$ & 94.7 \\
\hline Co Stearate & {$\left[\mathrm{Co}\left(\mathrm{CH}_{3}\left(\mathrm{CH}_{2}\right)_{1}, \mathrm{COO}\right)_{2}\right] \cdot 2 \mathrm{H}_{2} \mathrm{O}$} & $\begin{array}{l}65.29 \\
65.55\end{array}$ & $\begin{array}{l}11.25 \\
11.10\end{array}$ & $86-97$ & $\begin{array}{l}\text { Violet } \\
\text { powder }\end{array}$ & 97.7 \\
\hline NiStearate & {$\left[\mathrm{Ni}\left(\mathrm{CH}_{3}\left(\mathrm{CH}_{2}\right)_{1}, \mathrm{COO}\right)_{2}\right] \cdot 2 \mathrm{H}_{2} \mathrm{O}$} & $\begin{array}{l}65.35 \\
65.25\end{array}$ & $\begin{array}{l}11.26 \\
10.97\end{array}$ & $92-108$ & $\begin{array}{l}\text { Green } \\
\text { powder }\end{array}$ & 91 \\
\hline CuStearate & {$\left[\mathrm{Cu}\left(\mathrm{CH}_{3}\left(\mathrm{CH}_{2}\right)_{1}, \mathrm{COO}\right)_{2}\right] \mathrm{H}_{2} \mathrm{O}$} & $\begin{array}{l}66.67 \\
66.35\end{array}$ & $\begin{array}{l}11.18 \\
11.19\end{array}$ & $113-119$ & $\begin{array}{c}\text { Blue } \\
\text { powder }\end{array}$ & 93.4 \\
\hline Zn Stearate & {$\left[\mathrm{Zn}\left(\mathrm{CH}_{3}\left(\mathrm{CH}_{2}\right)_{1}, \infty O O\right)_{2}\right] \cdot \mathrm{H}_{2} \mathrm{O}$} & $\begin{array}{l}66.47 \\
66.40\end{array}$ & $\begin{array}{l}11.15 \\
11.18\end{array}$ & $173-195$ & $\begin{array}{l}\text { White } \\
\text { powder }\end{array}$ & 96.4 \\
\hline
\end{tabular}


Table (2) : I.R spectra for prepared metal stearates

\begin{tabular}{|c|c|c|c|c|c|c|c|}
\hline Compound & $\begin{array}{c}\text { Str. Vib. } \\
\text { O-H } \\
\left(\mathrm{cm}^{-1}\right)\end{array}$ & $\begin{array}{c}\text { Str. Vib. } \\
\text { C-H } \\
\left(\mathrm{cm}^{-1}\right)\end{array}$ & $\begin{array}{c}\text { Str. Vib. } \\
\text { (antisymm.) } \\
\mathrm{COO}^{-} \\
\left(\mathrm{cm}^{-1}\right)\end{array}$ & $\begin{array}{c}\text { Str. Vib. } \\
\text { (symm.) } \\
\mathrm{COO}^{-} \\
\left(\mathrm{cm}^{-1}\right)\end{array}$ & $\begin{array}{c}\text { Bending vib. } \\
\mathrm{COO}^{-} \\
\left(\mathrm{cm}^{-1}\right)\end{array}$ & $\begin{array}{c}\text { Str. Vib. } \\
\mathrm{C}=\mathrm{O} \\
\left(\mathrm{cm}^{-1}\right)\end{array}$ & $\begin{array}{c}\text { Bending } \\
\text { vib. } \\
\text { C-H } \\
\left(\mathrm{cm}^{-1}\right)\end{array}$ \\
\hline Stearic acid & $3400(\mathrm{~m})$ & $2930(\mathrm{~m})$ & - & - & - & $1695(s)$ & $750(\mathrm{~m})$ \\
\hline Fe stearate & $3451(\mathrm{~m})$ & $\begin{array}{l}2870(s) \\
2940(s)\end{array}$ & $\begin{array}{l}1540(s) \\
1466(s)\end{array}$ & $1460(s)$ & $938(w)$ & - & $722(\mathrm{~m})$ \\
\hline Co stearate & $3450(\mathrm{~m})$ & $\begin{array}{l}2860(s) \\
2940(s)\end{array}$ & $1560(\mathrm{~s})$ & $1460(s)$ & $910(w)$ & - & $726(\mathrm{~m})$ \\
\hline Ni stearate & $3454(\mathrm{~m})$ & $\begin{array}{l}2968(s) \\
2937(s)\end{array}$ & 1563 (s) & $\begin{array}{l}1460(s) \\
1435(s)\end{array}$ & $938(w)$ & - & $724(\mathrm{~m})$ \\
\hline Cu stearate & $3450(\mathrm{~m})$ & $\begin{array}{l}2870(s) \\
2940(s)\end{array}$ & $1565(\mathrm{~s})$ & $\begin{array}{l}1465(s) \\
1425(s)\end{array}$ & $925(w)$ & - & (m) 725 \\
\hline $\mathrm{Zn}$ stearate & $3450(\mathrm{~m})$ & $\begin{array}{l}2897(s) \\
2940(s)\end{array}$ & $1548(s)$ & $\begin{array}{l}1460(s) \\
1400(s)\end{array}$ & $925(w)$ & - & (m) 725 \\
\hline
\end{tabular}

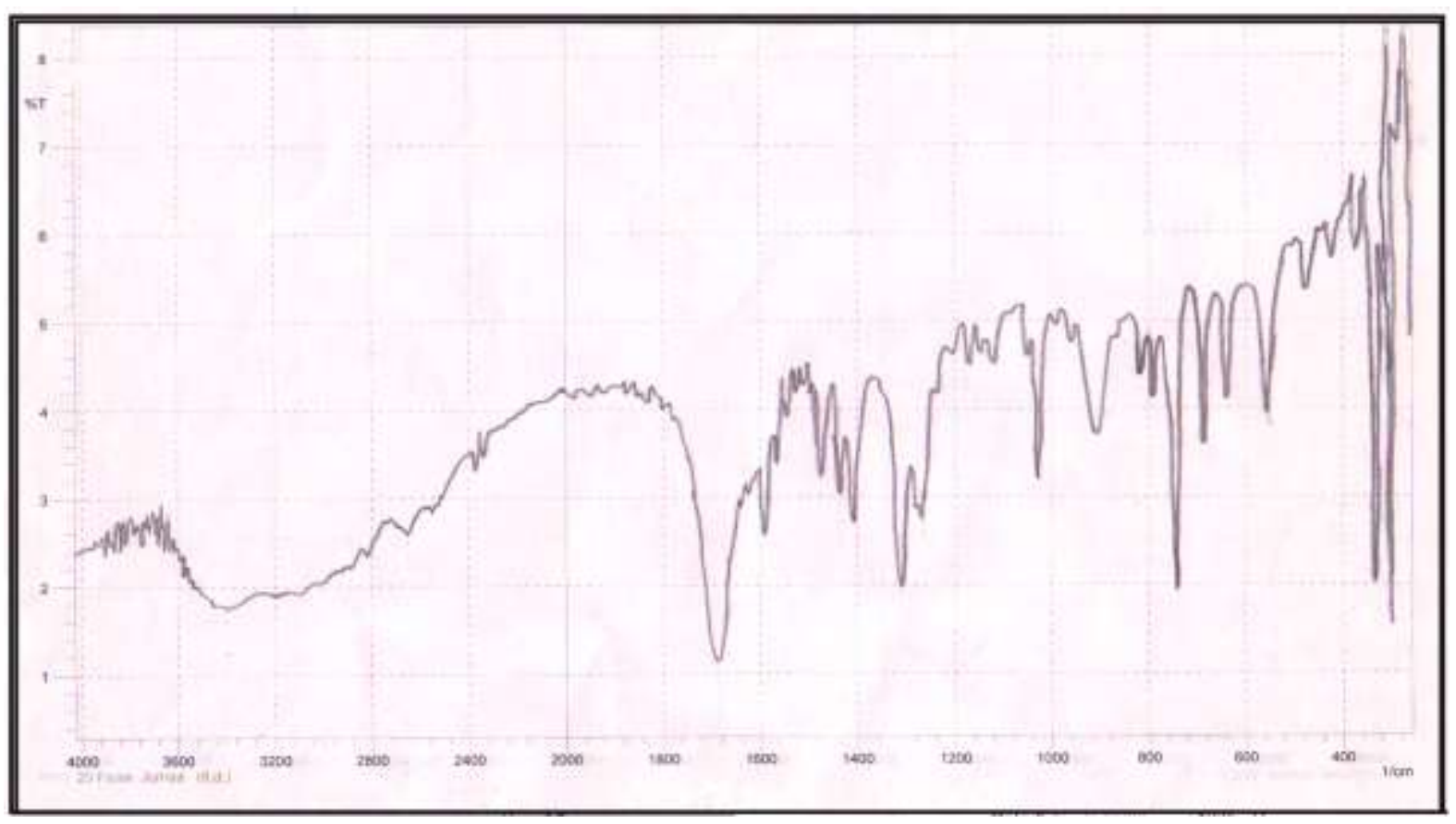

Fig (1): Infrared spectrum for stearic acid 


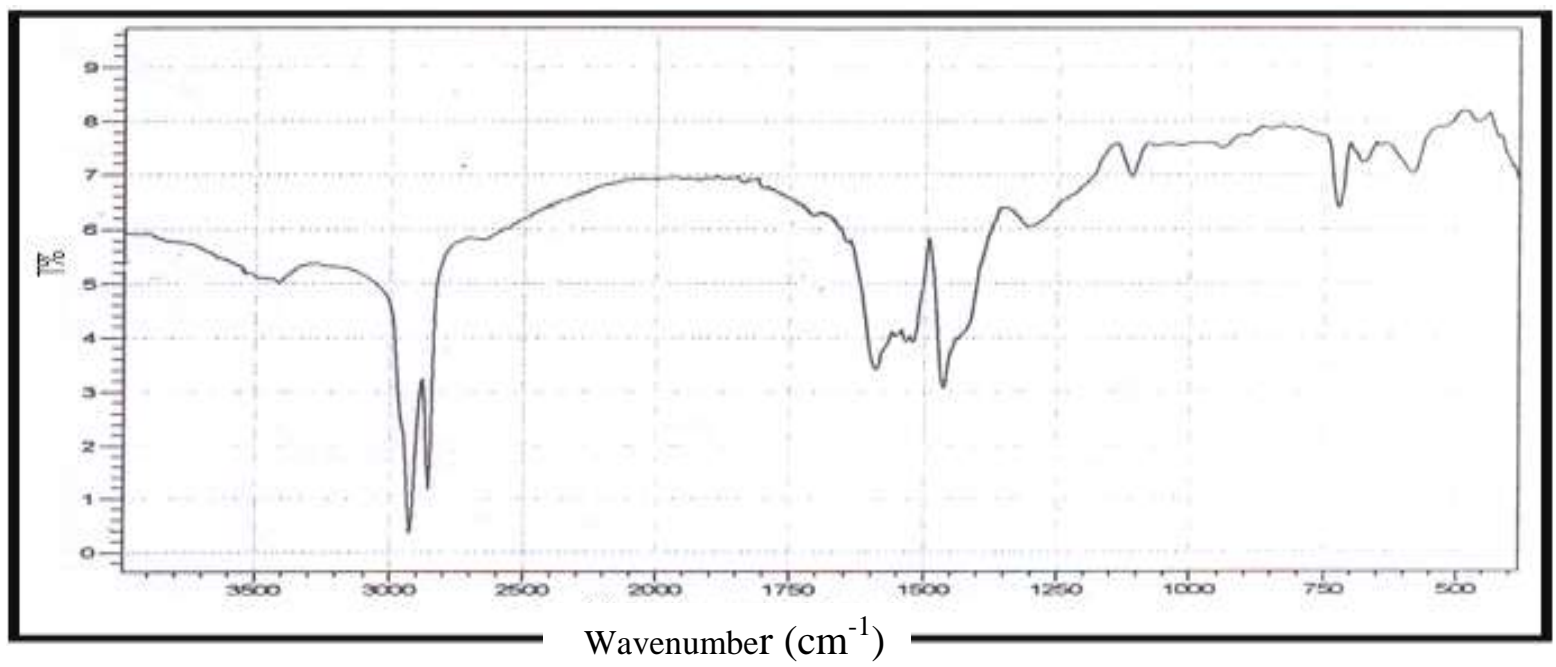

Fig (2): Infrared spectrum for Fe stearate

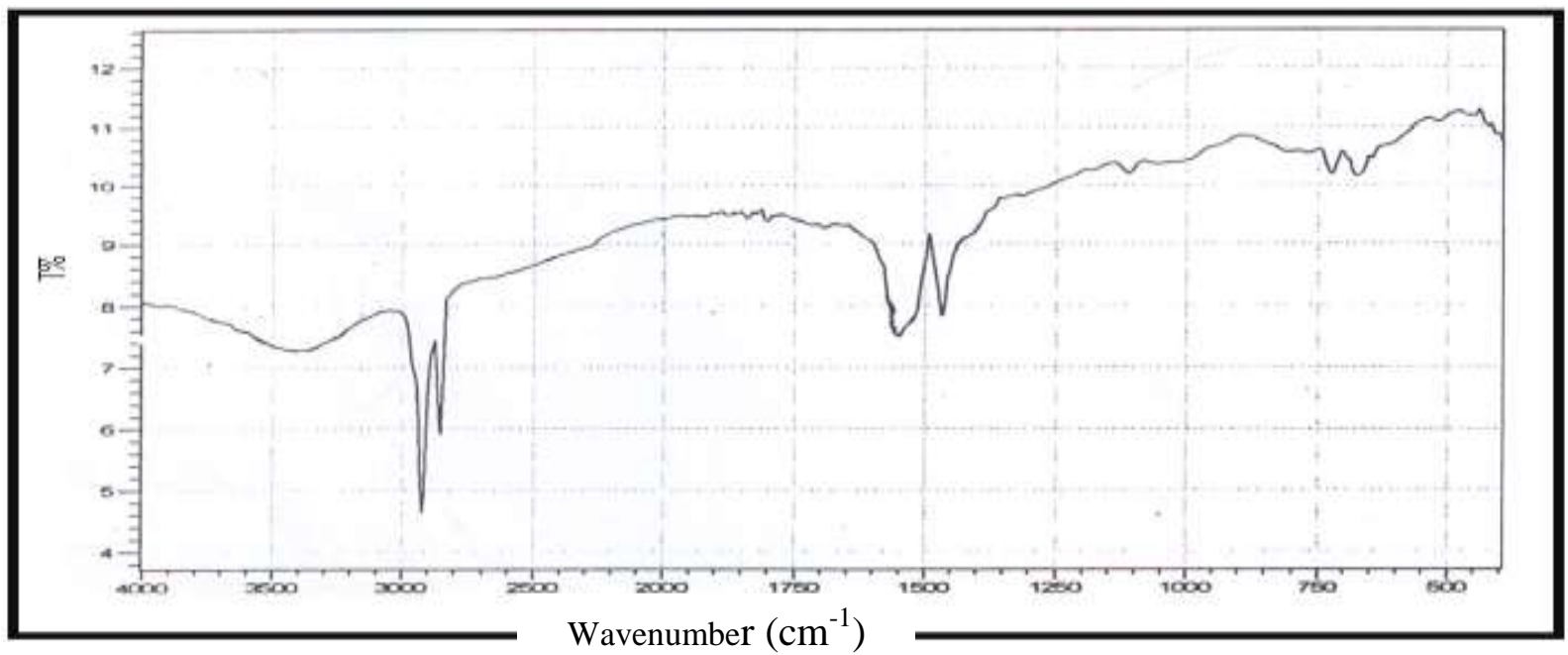

Fig (3): Infrared spectrum for Co stearate

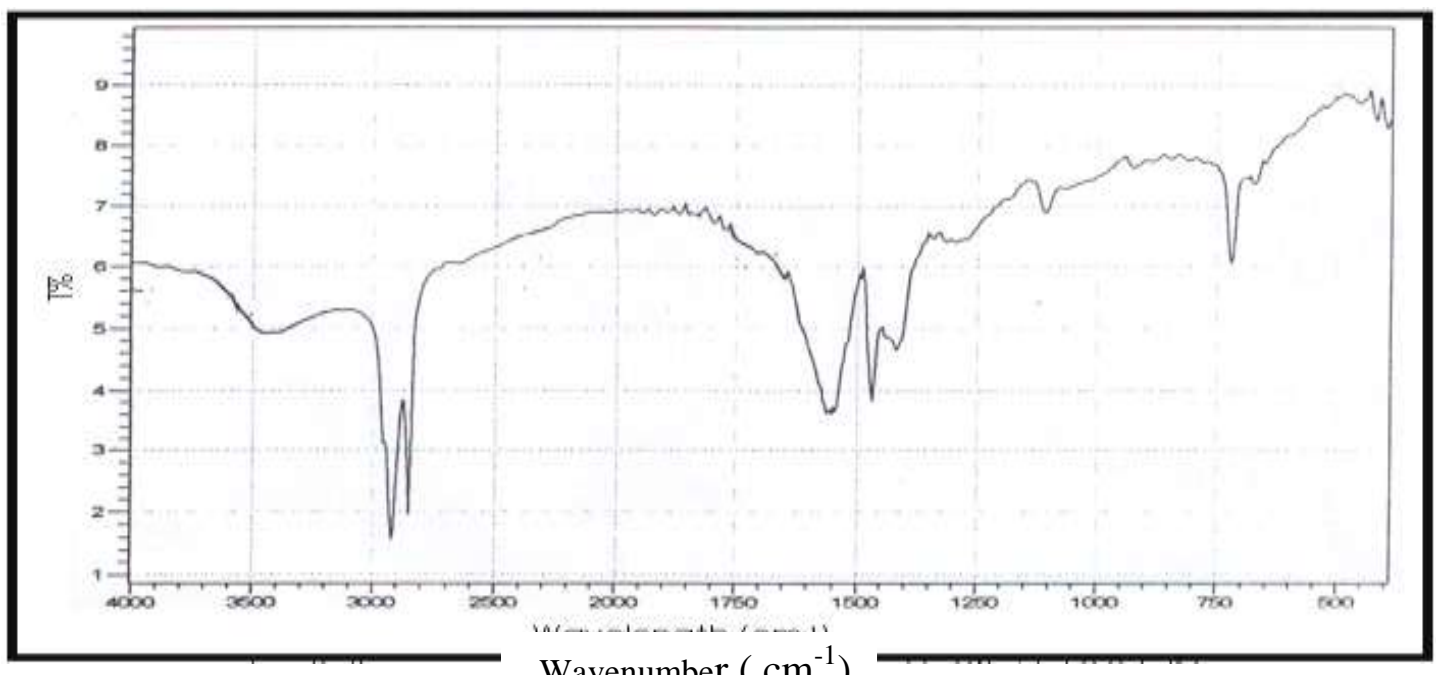

Fig (4): Infrared spectrum for Ni stearate 


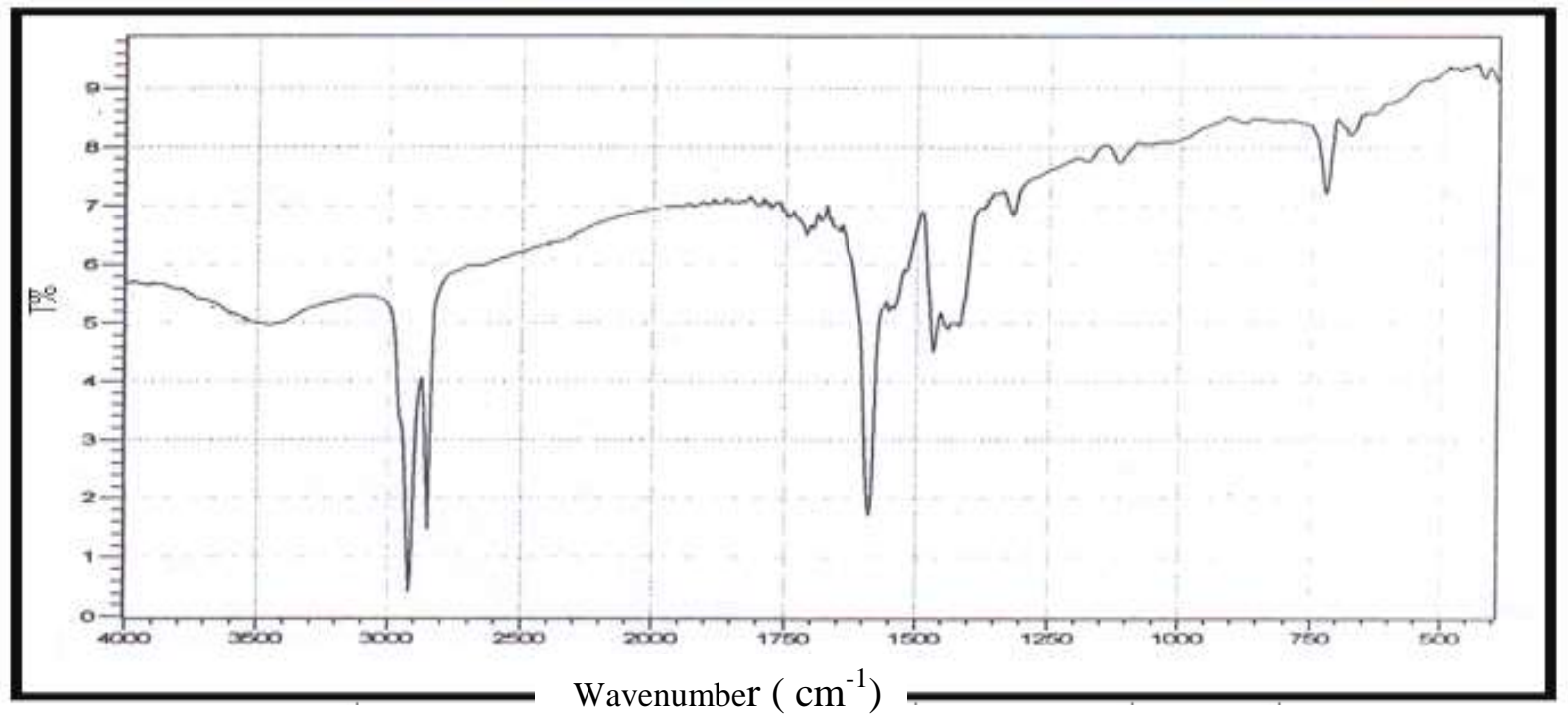

Fig (5): Infrared spectrum for $\mathrm{Cu}$ stearate

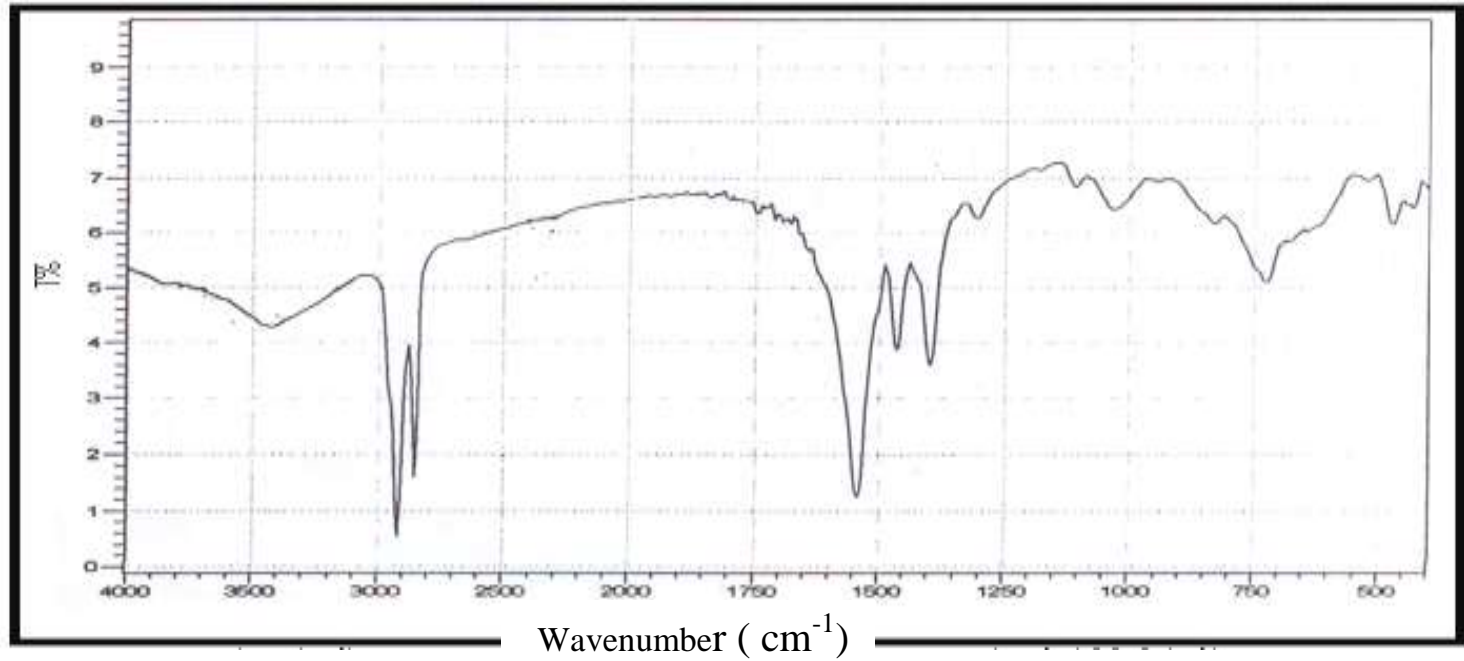

Fig (6): Infrared spectrum for Zn stearate

Infrared spectroscopy was studied for three absorption ranges ; antisymmetrical stretching vibration of $\mathrm{COO}^{-}$group $\left(1500-1600 \mathrm{~cm}^{-1}\right)$, stretching vibration of $\mathrm{C}=\mathrm{C}$ group ( 1600-1650 $\left.\mathrm{cm}^{-1}\right)$ and stretching vibration of $\mathrm{C}=\mathrm{O}$ group $(1700-1750$ $\left.\mathrm{cm}^{-1}\right)^{(16,17)}$ as shown in figures $(7)-($ 15)
Antisymmetrical stretching vibration of $\mathrm{COO}^{-}$group in the Nickel, Iron ,Cobalt, Zinc and Copper stearates was appeared in different positions at $1556,1575,1553,1545$ and 1560 $\mathrm{cm}^{-1}$ respectively because the site of this band is limited in cation attached with fatty acid. The results refer that the absorption of this band was 
decreased during the increasing time of thermal stress and to derived conclusions about the consumption of metal stearates because of the reaction of these stearates with hydrogen chloride evolved from PVC chain and formation of fatty acid ${ }^{(18,19)}$.

The important band lies near 1630 $\mathrm{cm}^{-1}$ that belong to $\mathrm{C}=\mathrm{C}$ bonds . This maximum lies somewhat lower that the characteristic absorption. The band may therefore be that of polyene or a group with double bond bearing chlorine or some other electronegative group in the vicinity. The $\mathrm{C}=\mathrm{O}$ group , whose wavenumber has been reduced by interaction with metal chloride, can not be ruled out ${ }^{(17)}$. The results show that imperviously changes in the absorption of this band with increasing degradation time .

On the other hand, the spectral range $1700-1750 \mathrm{~cm}^{-1}$ is included two bands at $1740 \mathrm{~cm}^{-1}$ and $1710 \mathrm{~cm}^{-1}$ that may be assumed two oxygen containing decomposition forms appeared during the degradation. The higher band was explained by the bond formation between stearates and the PVC chain to form ester group ${ }^{(15,18)}$ as shown below :

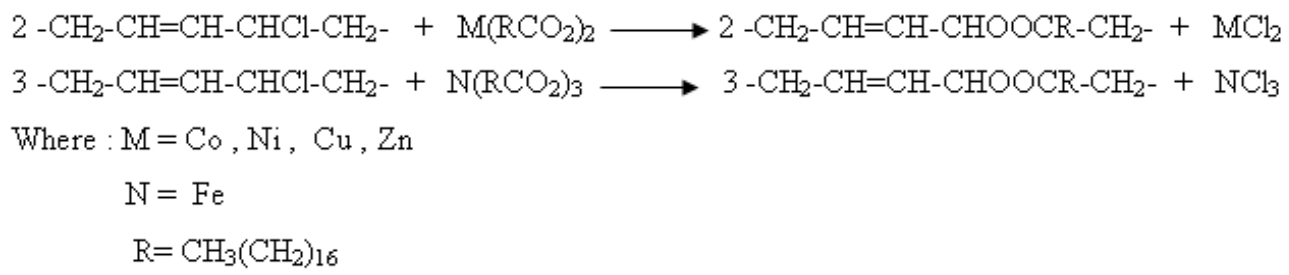

The other band at $1710 \mathrm{~cm}^{-1}$ lies in the typical range of ketons or the associated form of fatty acids, even if the formation of the acid due to the stearates reaction with $\mathrm{HCl}$ released during the degradation. However, it seems to be that band belong to either the carbonyl group formed on the PVC chain or the carbonyl group to the fatty acid formed by $\mathrm{HCl}$ and that in agreement with others ${ }^{(18,20)}$.

Ultraviolet visible spectroscopy is used to study the thermal degradation of unstabilised PVC and stabilized PVC reprecipitated from metal stearates. This was done by the investigation of the absorption of the polyenes resulted from the losing of $\mathrm{HCl}$ from the PVC chain at $275 \mathrm{~nm}$ and $385 \mathrm{~nm}$, which are corresponded to three and seven conjugated double bonds respectively ${ }^{(13,21)}$.

Table ( 3 ) and figures ( 16 ), (17) show that the intensity of absorption at $275 \mathrm{~nm}$ is higher than absorption at $385 \mathrm{~nm}$ because the concentration of polyenes contained three conjugated double bonds is great and formed firstly at exposure for thermal stress in comparison with polyenes contained seven conjugated double bonds .

On the other hand, the results indicated that $\mathrm{Fe}, \mathrm{Co}, \mathrm{Ni}$ and $\mathrm{Cu}$ stearates have the ability to stabilize PVC by decreasing the conjugated double bonds in the polymer chain, while $\mathrm{Zn}$ stearate was acted to increase the intensity of absorption for stabilized PVC in comparison with PVC alone at $275 \mathrm{~nm}$ and $385 \mathrm{~nm}$.

In order to increasing the stabilization efficiency for Zn stearate, the synergistic mixtures were prepared such as $\mathrm{Zn}-\mathrm{Fe}, \mathrm{Zn}-\mathrm{Co}, \mathrm{Zn}-\mathrm{Ni}$ and 
$\mathrm{Zn}-\mathrm{Cu}$ stearates. The results shown in table ( 3 ) and figures ( 18 ), (19) indicate that these mixtures have ability to increase the thermal stability of PVC and that is obviously during decreasing the intensity of absorption at $275 \mathrm{~nm}$ and $385 \mathrm{~nm}$.

Thermogravimetric analysis was used in the present study to evaluate the thermal stability for PVC containing prepared metal stearates . Several thermal stability parameters were determined such as decomposition temperature, half loss temperatue, total hydrogen chloride loss, rate of decomposition, activation energy and char content. The results shown in table ( 4 ) and figures (20)(25) indicate that all metal stearates ( except $\mathrm{Zn}$ stearate) increase the thermal stability of PVC, and this is obviously during improvement of all thermal stability parameters. This thermal stability is due to the ability of the metal stearates to reduce the dehydrochlorination of PVC and that means reducing the catalytic effect of hydrogen chloride on the PVC degradation which interact with double bonds of dehydrochlorination chain $(13,22)$.

To improve the stabilizing rule of $\mathrm{Zn}$ stearate, the synergistic effect of $\mathrm{Zn}$ stearate mixed with $\mathrm{Fe}, \mathrm{Co}, \mathrm{Ni}$ and $\mathrm{Cu}$ stearates was studied. The results shown in table ( 4 ) and figures (26) - (29) indicate that thermal stability of PVC stabilized with these mixtures increase in comparison with PVC alone. The stabilization of PVC can be carried out probably according to the following mechanism ${ }^{(3,8,23)}$ :

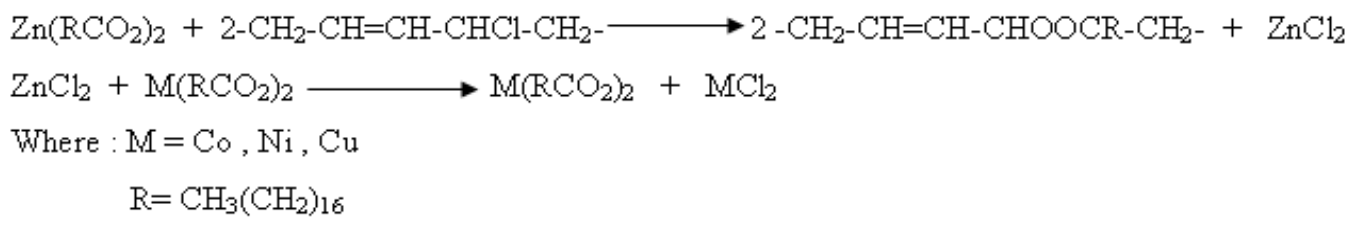

These equations show that $\mathrm{Zn}\left(\mathrm{RCO}_{2}\right)_{2}$ have ability to form ester bonding with $\mathrm{PVC}$ chain to result $\mathrm{MCl}_{2}$ which act as lious acid increased the dehydrochlorination, but the presence of $\mathrm{M}\left(\mathrm{RCO}_{2}\right)_{2}$ leads to the variation of $\mathrm{ZnCl}_{2}$ into inactive molecule, then the reestrification process take $\mathrm{pl}$

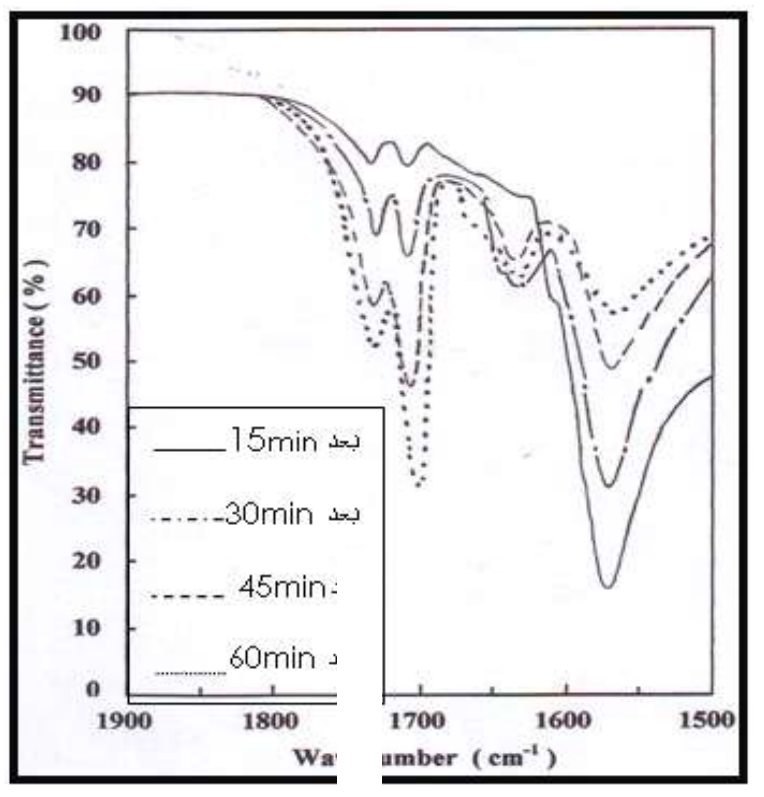

Fig (7): Infrared spectra for PVC films stabilized with Fe stearate in the degradation at $195^{\circ} \mathrm{C}$ in air 


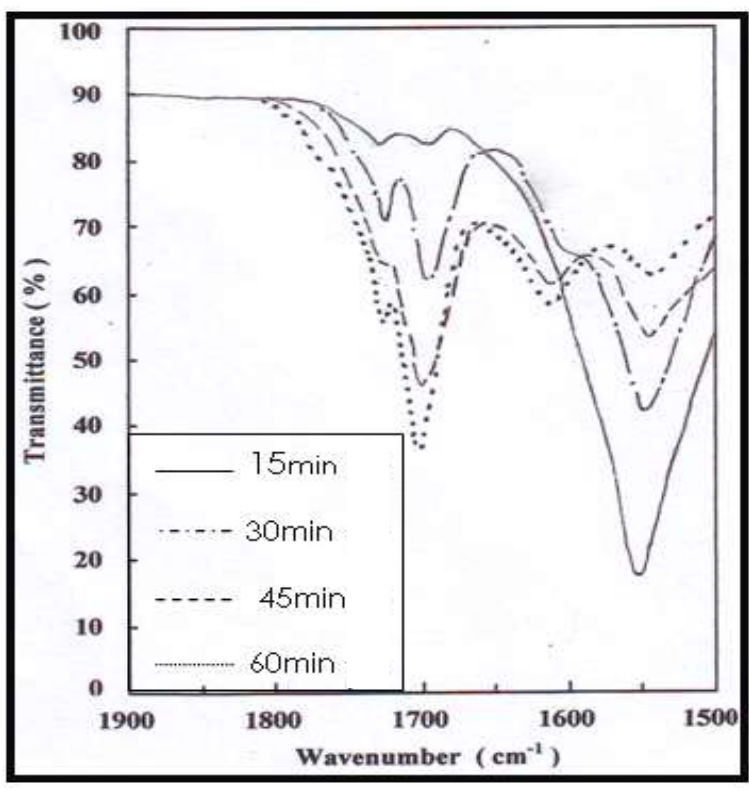

Fig (8): Infrared spectra for PVC films stabilized with Co stearate in the degradation at $195^{\circ} \mathrm{C}$ in air

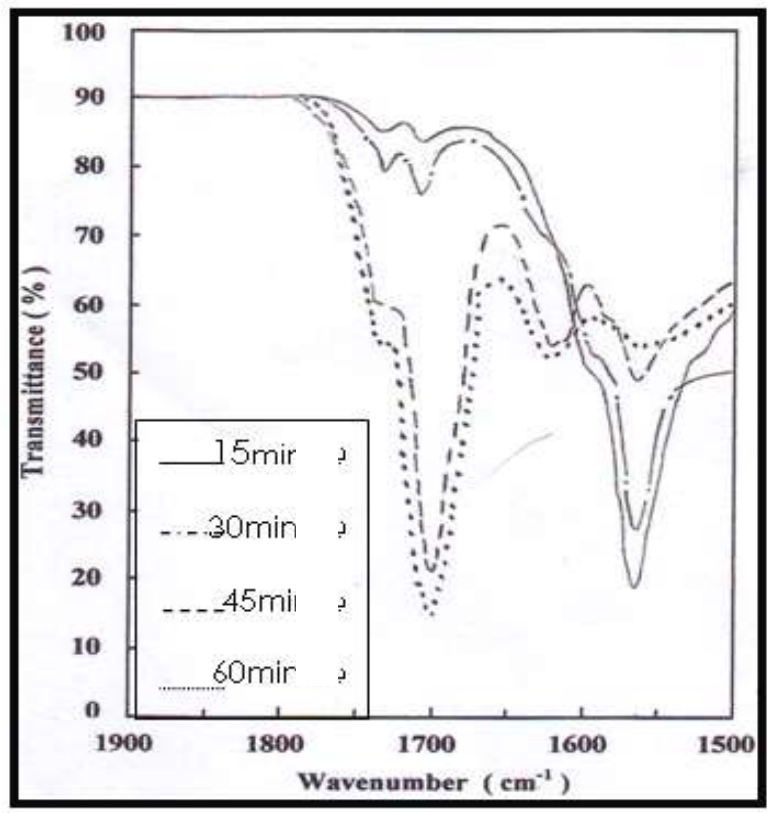

Fig (10): Infrared spectra for PVC films stabilized with $\mathrm{Cu}$ stearate in the degradation at $195{ }^{\circ} \mathrm{C}$ in air

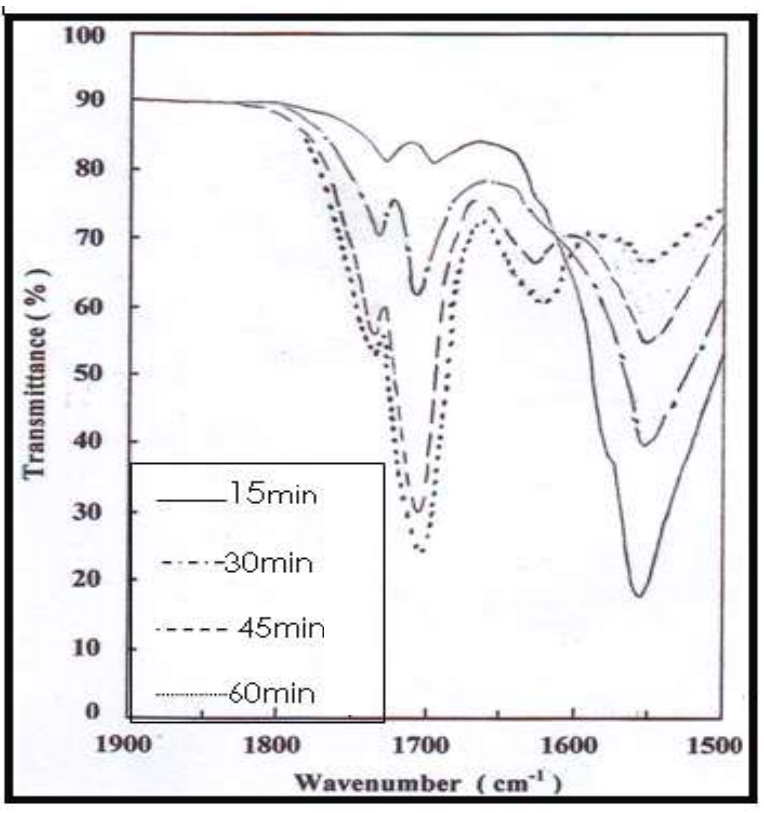

Fig (9): Infrared spectra for PVC films stabilized with Ni stearate in the degradation at $195{ }^{\circ} \mathrm{C}$ in air

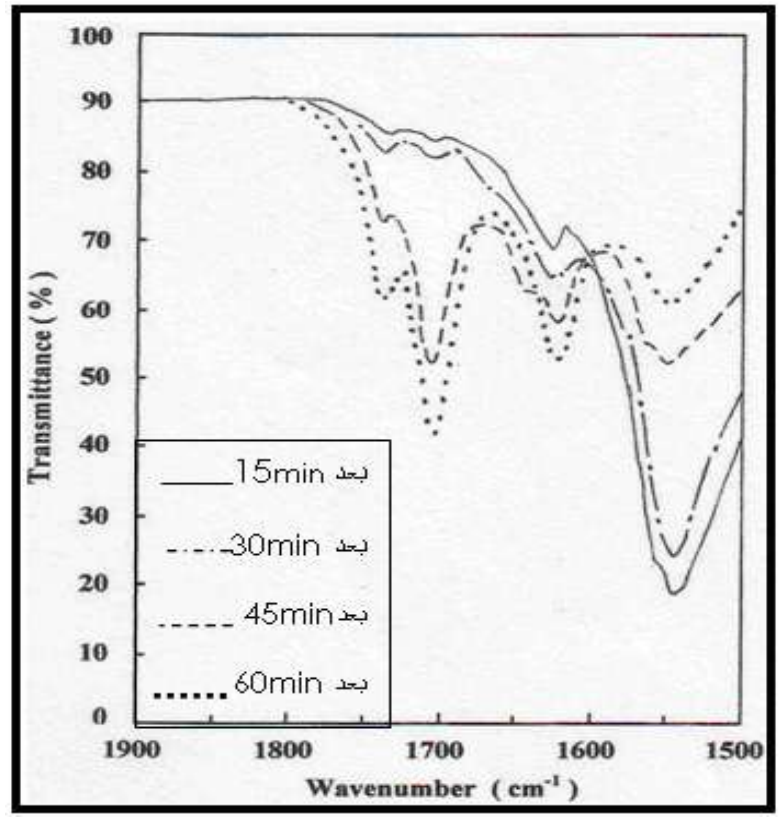

Fig (10): Infrared spectra for PVC films stabilized with $\mathrm{Zn}$ stearate in the degradation at $195{ }^{\circ} \mathrm{C}$ in air 


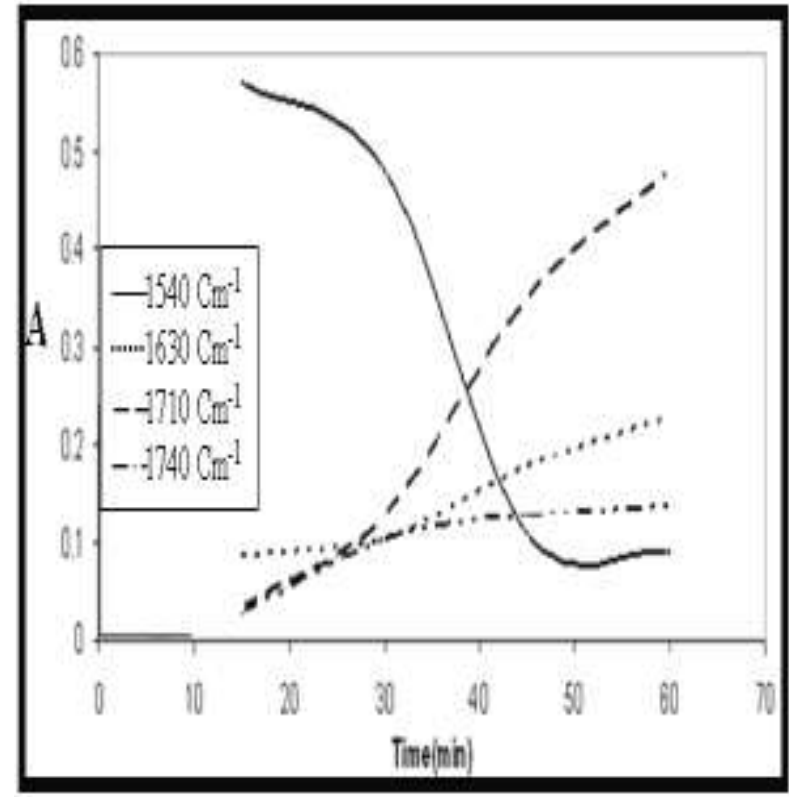

Fig (11): Dependence of the peaks for PVC films stabilized with $\mathrm{Fe}$ stearate on the time of thermal degradation at $195{ }^{\circ} \mathrm{C}$ in air $[\mathrm{Ai}=$ $\log (\mathrm{T} 1800 / \mathrm{Ti})]$

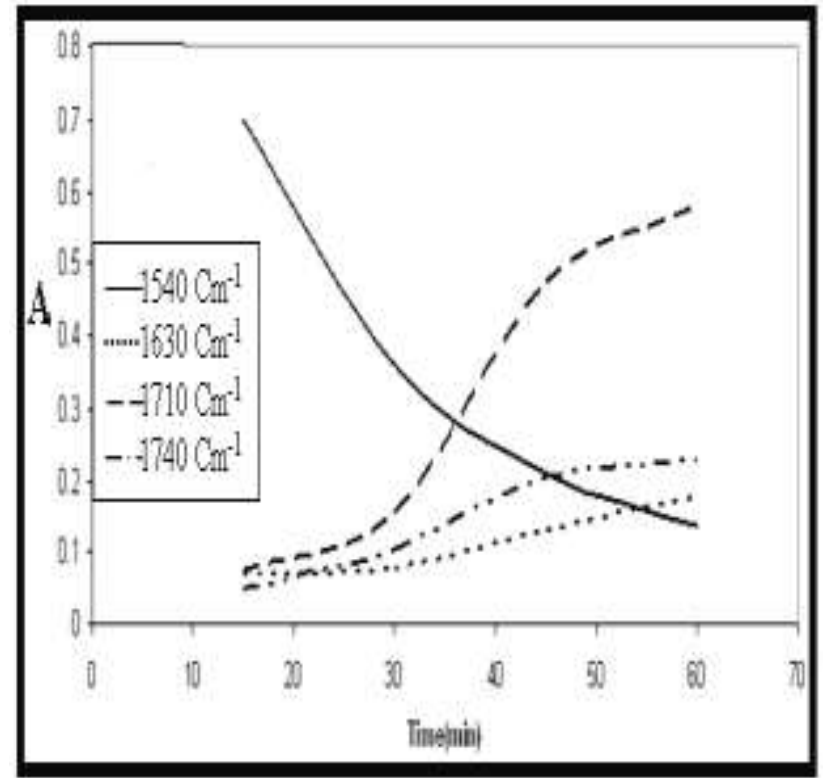

Fig (13): Dependence of the peaks for PVC films stabilized with Ni stearate on the time of thermal degradation at $195^{\circ} \mathrm{C}$ in air $[\mathrm{Ai}=\log (\mathrm{T} 1800 /$ Ti)]

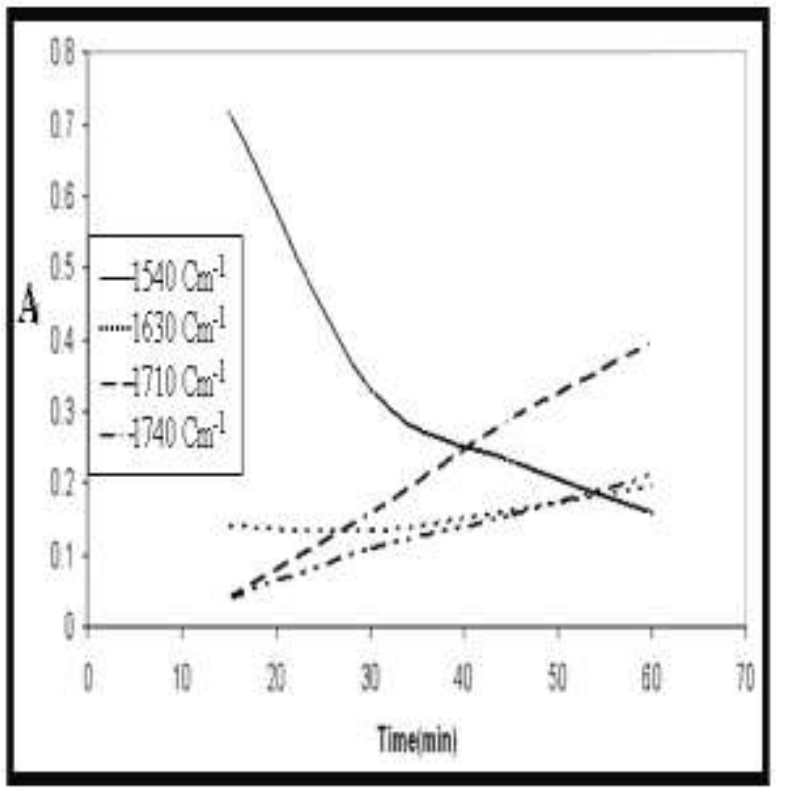

Fig (12): Dependence of the peaks for PVC films stabilized with Co stearate on the time of thermal degradation at $195^{\circ} \mathrm{C}$ in air $[\mathrm{Ai}=\log$ (T1800/ Ti)]

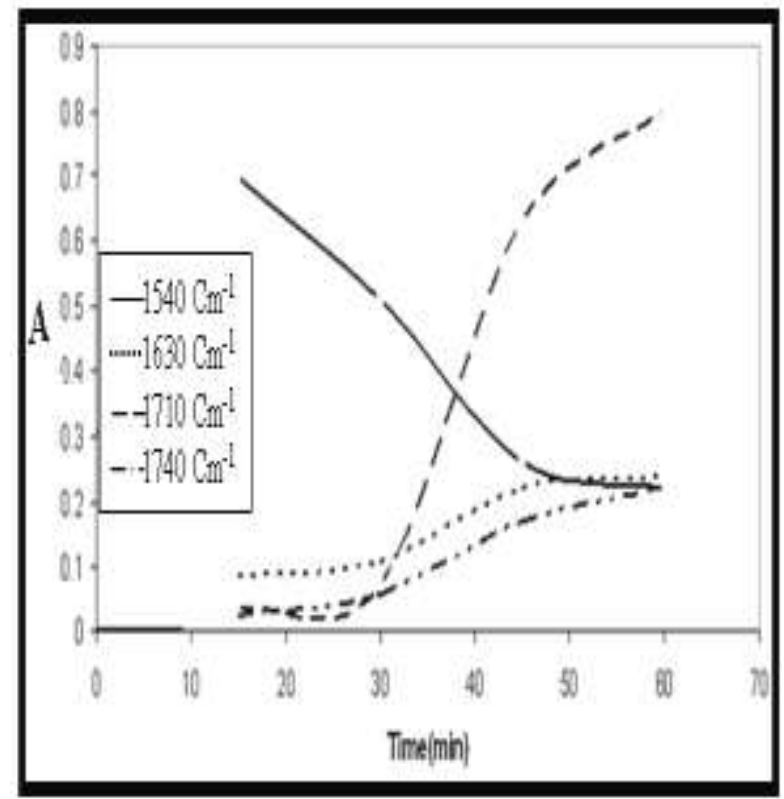

Fig (14): Dependence of the peaks for PVC films stabilized with $\mathrm{Cu}$ stearate on the time of thermal degradation at $195{ }^{\circ} \mathrm{C}$ in air [Ai $=\log (\mathrm{T} 1800 / \mathrm{Ti})]$ 
Table (3): Values of absorbances for unstabilized PVC and PVC reprecipitated from metal stearates at $275 \mathrm{~nm}$ and $385 \mathrm{~nm}$

\begin{tabular}{|c|c|c|c|c|c|c|c|c|}
\hline \multirow[t]{3}{*}{ Compound } & \multicolumn{4}{|c|}{ Absorbance at $385 \mathrm{~nm}$} & \multicolumn{4}{|c|}{ Absorbance at $275 \mathrm{~nm}$} \\
\hline & \multicolumn{4}{|c|}{ Time of thermal stress (min) } & \multicolumn{4}{|c|}{ Time of thermal stress (min) } \\
\hline & 15 & 30 & 45 & 60 & 15 & 30 & 45 & 60 \\
\hline Unstabilized PVC & 0.136 & 0.185 & 0.232 & 0.343 & 0.253 & 0.398 & 0.643 & 0.895 \\
\hline PVC+Fe-stearate & 0.111 & 0.146 & 0.2 & 0.281 & 0.112 & 0.288 & 0.596 & 0.816 \\
\hline PVC+Co-stearate & 0.086 & 0.114 & 0.177 & 0.256 & 0.072 & 0.25 & 0.561 & 0.751 \\
\hline PVC+Ni-Stearate & 0.072 & 0.106 & 0.167 & 0.24 & 0.061 & 0.234 & 0.514 & 0.731 \\
\hline PVC+Cu-stearate & 0.092 & 0.123 & 0.184 & 0.265 & 0.083 & 0.265 & 0.58 & 0.794 \\
\hline pvc $+Z$ n-stearate & 0.143 & 0.188 & 0.237 & 0.351 & 0.264 & 0.411 & 0.665 & 0.899 \\
\hline $\mathrm{PVC}+Z_{n}$-Fe-stearate & 0.118 & 0.16 & 0.211 & 0.306 & 0.176 & 0.326 & 0.586 & 0.843 \\
\hline pVC+ $+Z$-Co-stearate & 0.092 & 0.134 & 0.183 & 0.271 & 0.14 & 0.282 & 0.527 & 0.793 \\
\hline PVC+ $+Z_{n}$-Ni-stearate & 0.084 & 0.126 & 0.173 & 0.261 & 0.114 & 0.246 & 0.505 & 0.769 \\
\hline $\mathrm{PVC}+\mathrm{Zn}_{\mathrm{n}}$-Cu-stearate & 0.107 & 0.142 & 0.2 & 0.29 & 0.154 & 0.3 & 0.568 & 0.814 \\
\hline
\end{tabular}


Table (4): Some parameters of thermal stability for PVC stabilized with prepared metal stearates

\begin{tabular}{|c|c|c|c|c|c|}
\hline \multirow{2}{*}{ Compound } & \multicolumn{2}{|c|}{ Decomposition temperature $\left({ }^{\circ} \mathrm{C}\right)$ from } & \multirow{2}{*}{$\begin{array}{c}\text { Total } \\
\text { HCl } \\
\text { Loss(\%) }\end{array}$} & \multirow{2}{*}{$\begin{array}{l}\text { Rate of } \\
\text { Decomp. } \\
\text { (w\%/min) }\end{array}$} & \multirow{2}{*}{$\begin{array}{c}\text { Activation energy } \\
\text { at } 300-350{ }^{0} \mathrm{C} \\
(\text { KJ.mole } \\
\text {-1 })\end{array}$} \\
\hline & $50 \%$ decomp. & DT & & & \\
\hline Unstabilized PVC & 337.5 & 286.5 & 62.0 & 7.05 & 131 \\
\hline PVC+Fe-Stearate & 352.0 & 298.0 & 60.0 & 5.6 & 170.66 \\
\hline PVC+Co- Stearate & 375.0 & 313.0 & 61.1 & 3.66 & 249.42 \\
\hline PVC+Ni-Srearate & 376.0 & 325.0 & 60.1 & 3.35 & 270.21 \\
\hline $\mathrm{PVC}+\mathrm{Cu}-$ Stearate & 357.0 & 304.5 & 60.0 & 4.93 & 190.03 \\
\hline PVC+Zn-Stearate & 330.0 & 267.0 & 62.9 & 8.16 & 129.78 \\
\hline PVC $+\mathrm{Zn}-\mathrm{Fe}-$ Stearate & 349.0 & 287.5 & 60.1 & 7.036 & 141.34 \\
\hline PVC+Zn-Co-Stearate & 357.0 & 306.0 & 60.0 & 6.0 & 145.5 \\
\hline $\mathrm{PVC}+\mathrm{Zn}-\mathrm{Ni}$-Stearate & 375.0 & 308.0 & 60.0 & 5.7 & 172.7 \\
\hline PVC+Zn-Cu-Stearate & 356.5 & 300.0 & 60.0 & 7.013 & 142.53 \\
\hline
\end{tabular}

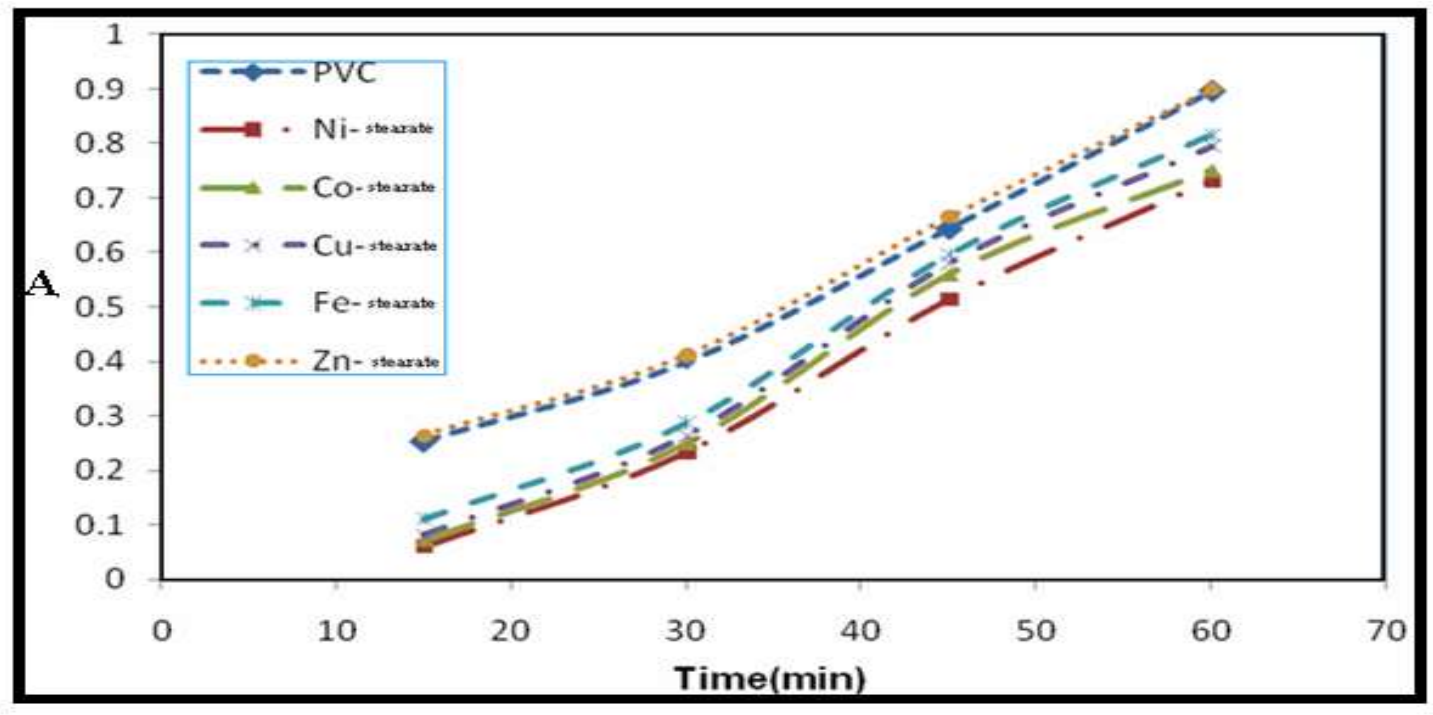

Fig (16): Dependence of absorbance for PVC films stabilized with prepared metal stearates at $275 \mathrm{~nm}$ on the time of thermal degradation at $195^{\circ} \mathrm{C}$ in air 


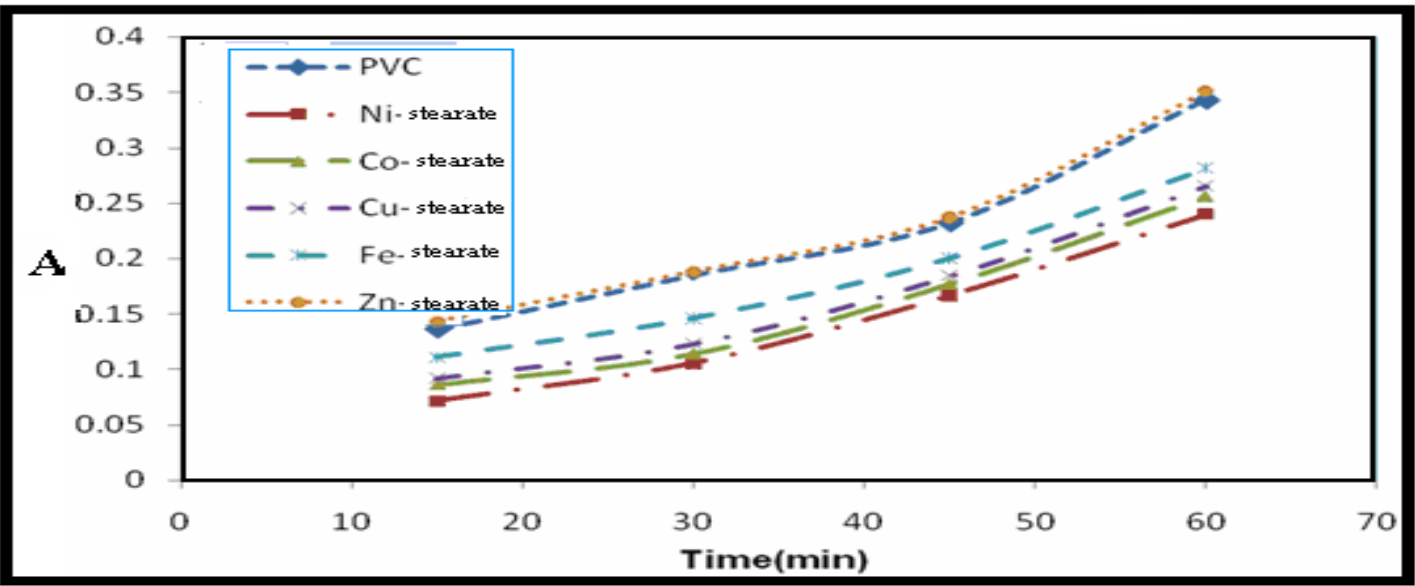

Fig (17): Dependence of absorbance for PVC films stabilized with prepared metal stearates at $385 \mathrm{~nm}$ on the time of thermal degradation at $195^{\circ} \mathrm{C}$ in air

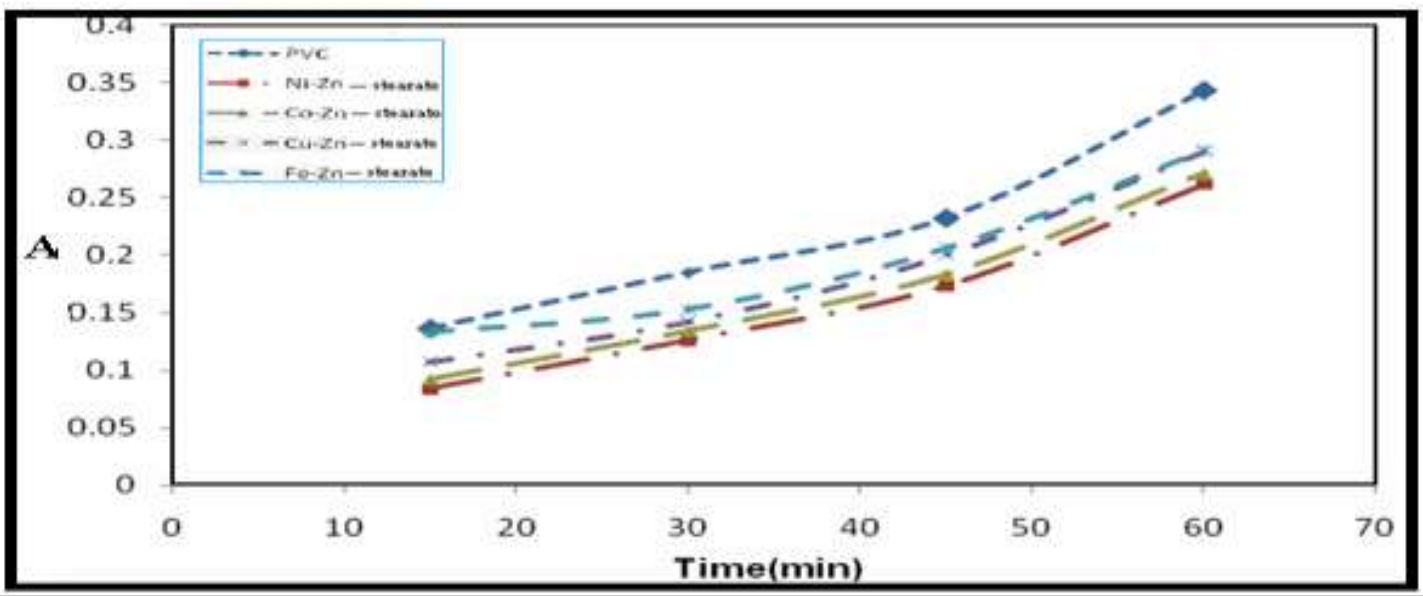

Fig (18): Dependence of absorbance for PVC films stabilized with synergistic mixtures of prepared metal stearates at $275 \mathrm{~nm}$ on the time of thermal degradation at $195{ }^{\circ} \mathrm{C}$ in air

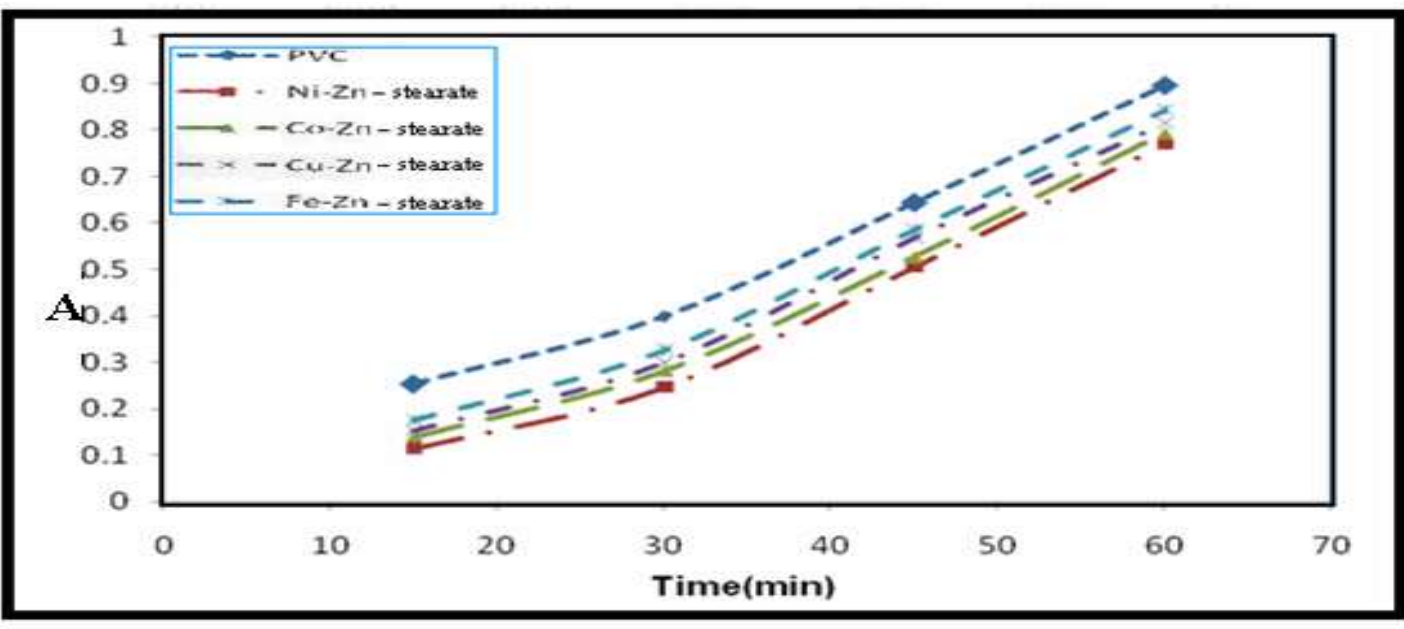

Fig (19): Dependence of absorbance for PVC films stabilized with synergistic mixtures of prepared metal stearates at $385 \mathrm{~nm}$ on the time of thermal degradation at $195{ }^{\circ} \mathrm{C}$ in air 


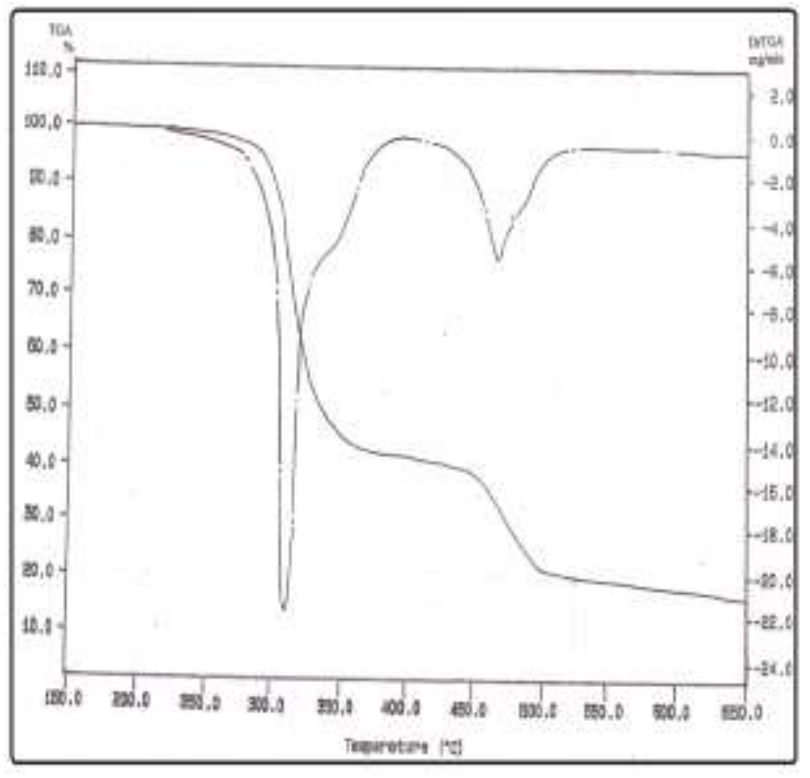

Fig (20): TGA curve for unstabilized PVC

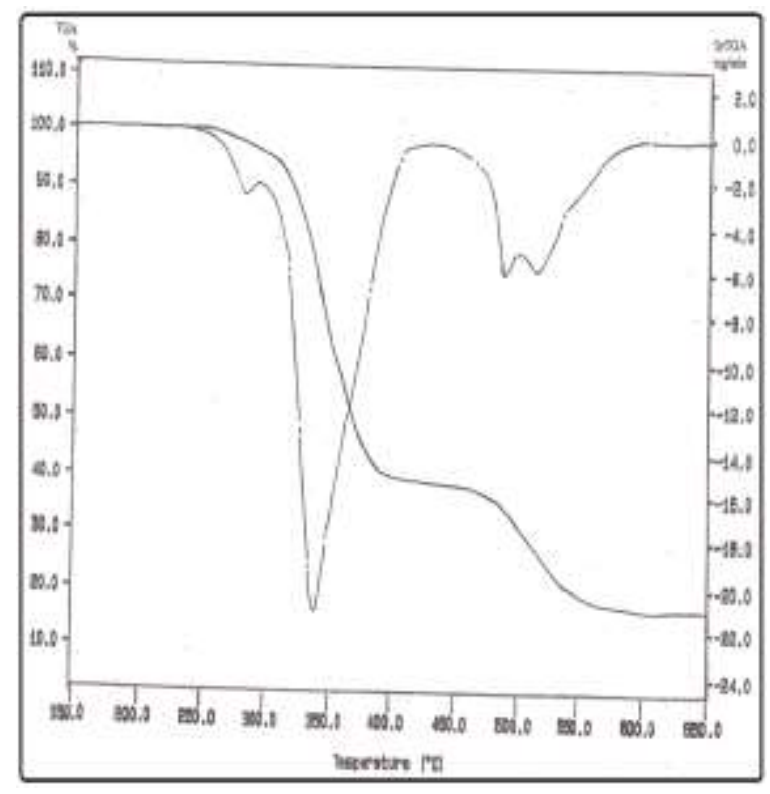

Fig (22): TGA curve for PVC stabilized with Co stearate

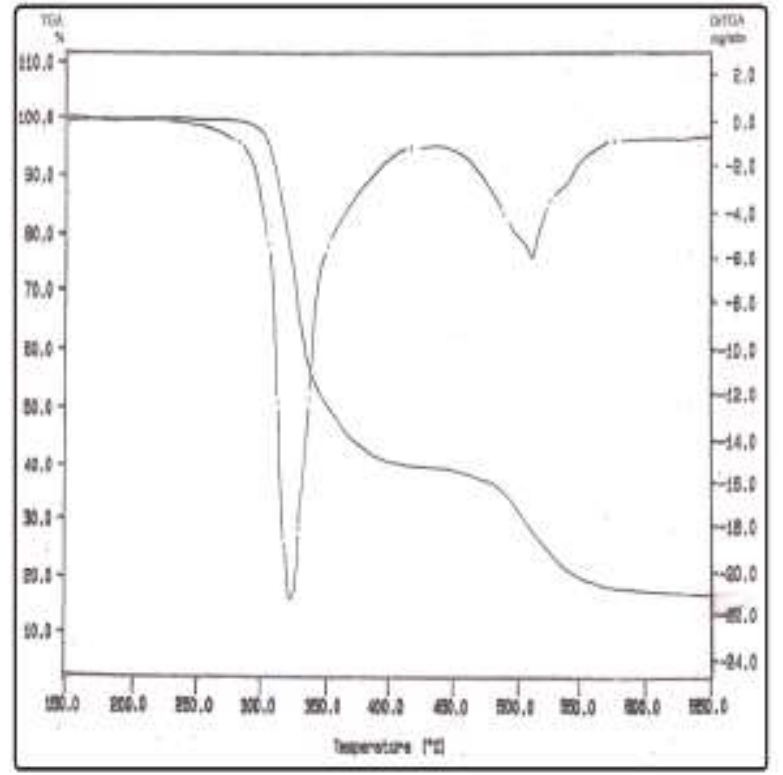

Fig (21): TGA curve for PVC stabilized with Fe stearate

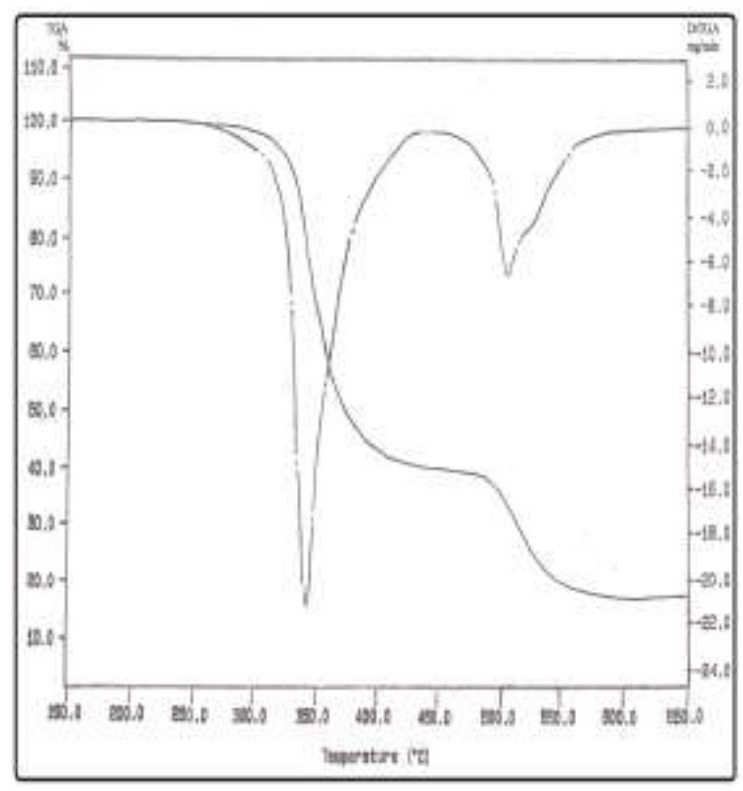

Fig (23): TGA curve for PVC stabilized with $\mathrm{Ni}$ stearate 


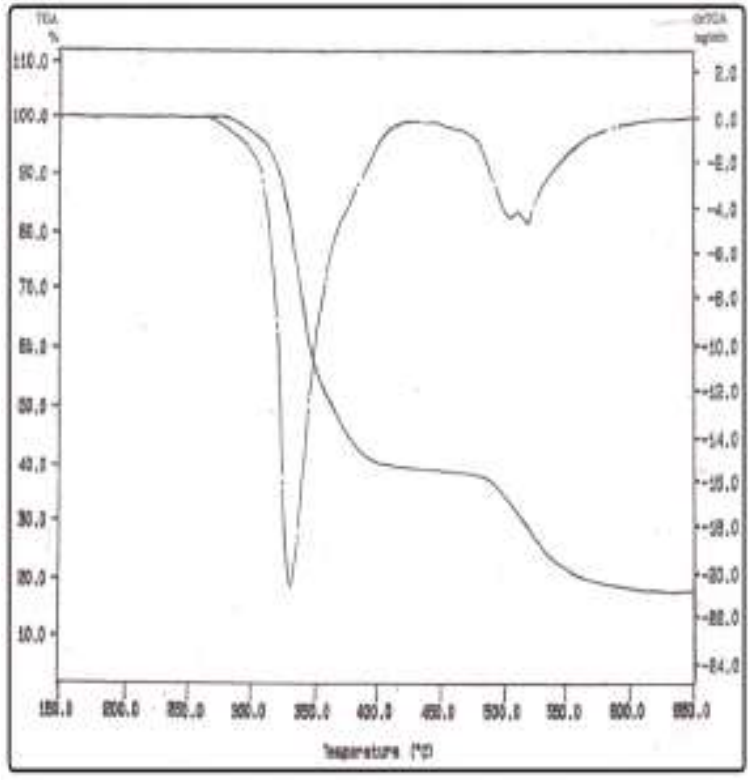

Fig (24): TGA curve for PVC stabilized with $\mathrm{Cu}$ stearate

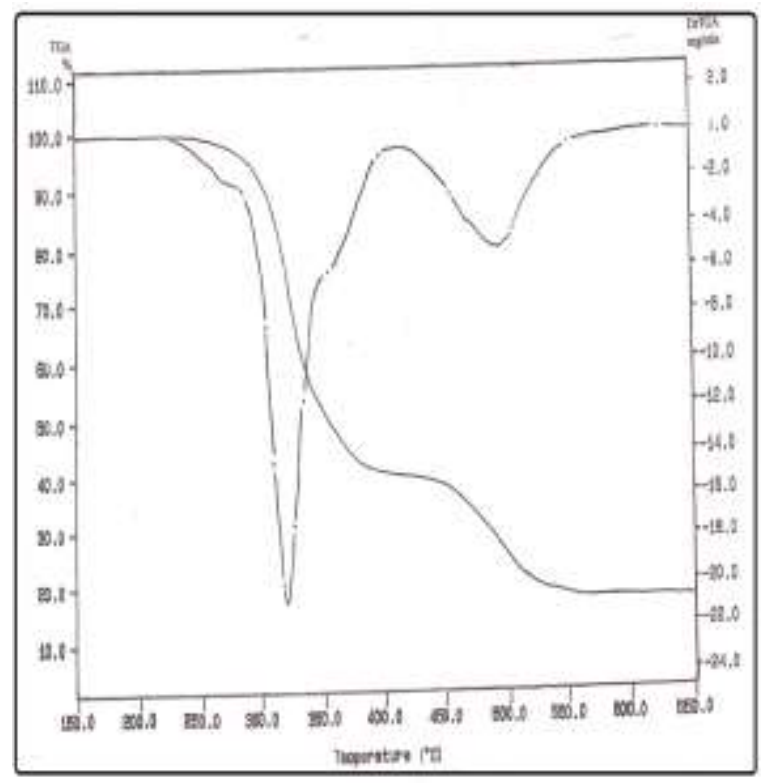

Fig (26): TGA curve for PVC stabilized with $\mathrm{Zn}$-Fe stearate

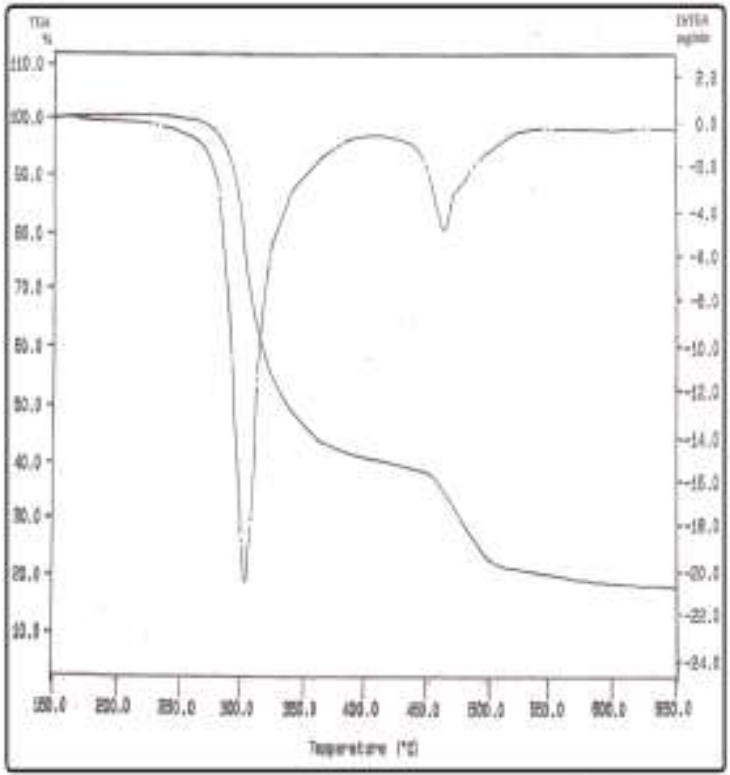

Fig (25): TGA curve for PVC stabilized with $\mathrm{Zn}$ stearate

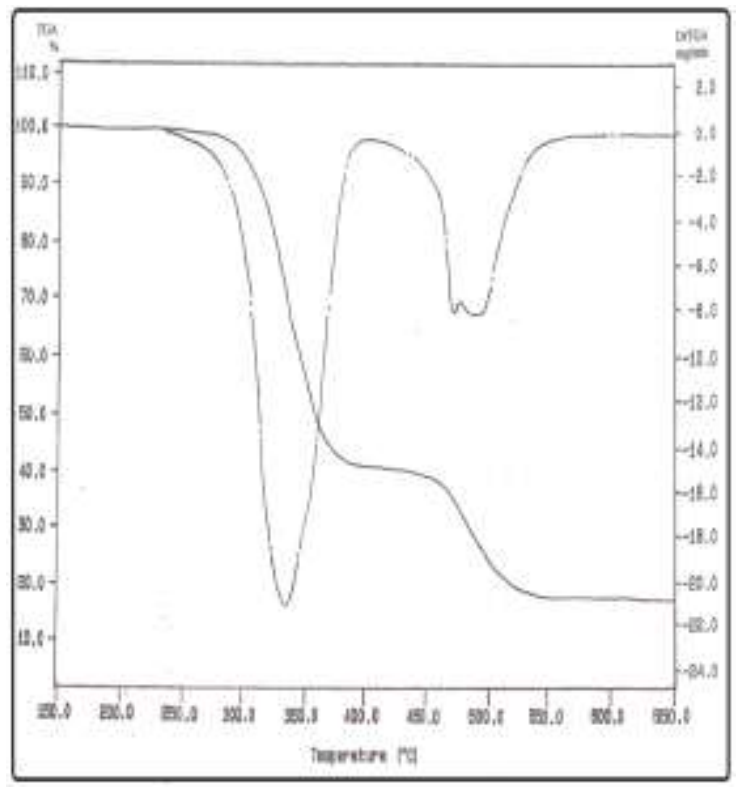

Fig (27): TGA curve for PVC stabilized with Zn-Co stearate 


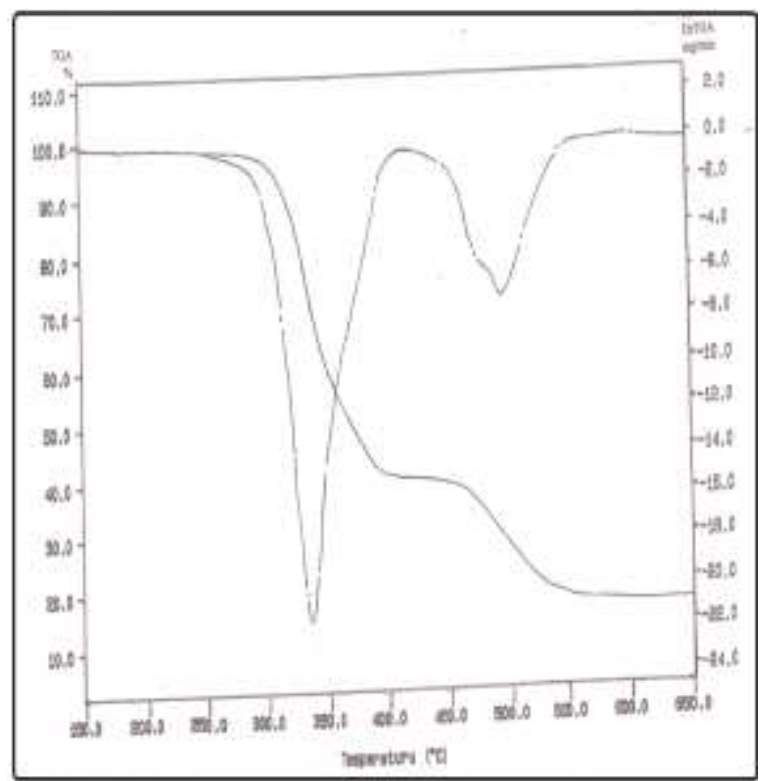

Fig (28): TGA curve for PVC stabilized with Zn-Ni stearate

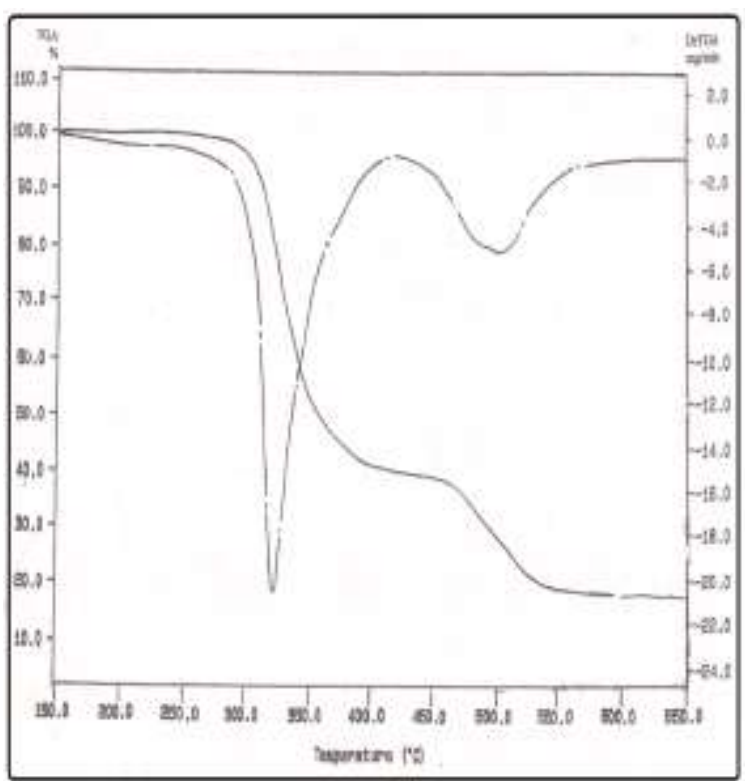

Fig (29): TGA curve for PVC stabilized with $\mathrm{Zn}-\mathrm{Cu}$ stearate

\section{Reference}

1- L.J.Gonzalez , M.Arellano , M.Sanchez and E.Mendizabal , Polym. Degrad. Stab. , 91, 2715 (2006) .

2- W.V.Titow , PVC Technology, 4th Edition, Elsevier Applied Science Publishers, London and New York, (1985) .

3- Y.B.Liu , W.Q.Liu and M.H.Hou , Polym. Degrad. Stab. , 92 , 1565 (2007) .

4- E.Ureta and M.Cantu, J. Appl. Polym. Sci. ,77, 2603 (2000).

5- R.Bacaloglu and M.Fisch, PVC Stabilizers, in : H.Zweifel, Plastic Additives Handbook, 5th Edition, Munich, Hanser, Chap. 3 , (2001) .

6- W.Manzoor, S.Yousaf and Z.Ahmad, Polym. Degrad. Stab. , 51 , 295 (1996) .

7- R.Benavides , M.Edge and M.S.Allen, Polym. Degrad. Stab. ,44 , 375 (1994) .

8- M.Onozuka, J. Polym. Sci. , $\underline{5}$, 2229 (1967) .

9- R.Benavides , M.Edge and M.S.Allen, Polym. Degrad. Stab. ,499, 205 (1995) .

10- R.Hussain and F.Mahmood, J. Chem. Soc. Pak. , $\underline{16}$, 225 (1994) .

11- M.Y.Kadhum and H.A.Jasim, J. Basrah Researches, 28 , 35 (2002) .

12- Z.Ahmad and M.Saleem, J. Chem. Soc. Pak. , $\underline{6}$, 191 (1984) .

13- Z.Vymazal, E.Czako, K.Volka, J.Stepek, R.Lukas, M.Kolinsky and K.Bouchal, Eur. Polym. J. , $\underline{16}, 151(1980)$.

14- Z.Vymazal , L.Mastny and Z.Vymazalova, Eur. Polym. J. , 25 , 1069 (1989) .

15- Z.Vymazal, Scientific Papers of the Technical University of Szczecin , P. 53, 1994.

16- E.Czako, Z.Vymazal, K.Volka , I.Stibor and J.Stepek, Eur. Polym. J. , 15 , 81 (1979) .

17- K.Volka , Z.Vymazal , T.Zajicek and Z.Vymazalova, Eur. Polym. J. , 17, 1189 (1981) .

18- K.Volka , J.Skorvaga and Z.Vymazal , Spectrochemica Acta , 44 , 1341 (1988) .

19- M.Y.Kadhum , J. Basrah Researches, 25 , 44 (2000) .

20- M.W.Mackenzie, H.A.Wills , R.C.Owen and A.Michel , Eur. Polym. J. , 19 , 511 (1983) . 
21- Z.Vymazal , E.Czako , K.Volka and J.Stepek, in : Developments in Polymer Degradation - 4 ( Edited by N.Grassie ), P. 71 , Applied Science, London, 1982 .

22- M.Ashraf Khan, S.Shah and Z.Ahmad, Iranian Polym. J. , 5, 251 (1996) .

23- H.Baltacioglu and D.Balkose , J. Appl. Polym. Sci. , 74 , 2488 (1999) .

در اسة الثبات الحر اري لبولي كلوريد الفاينيل بوجود سترات العناصر الفلزية

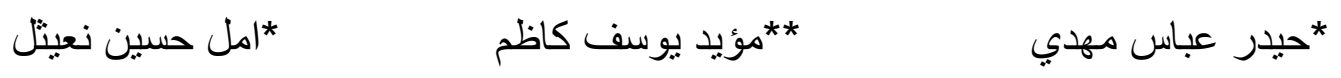

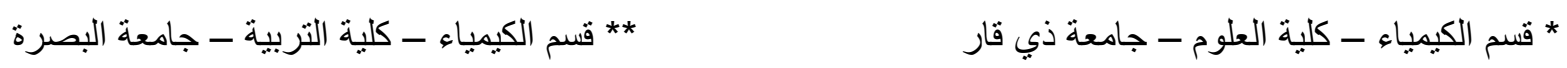

الملخص

ضدنت الدراسة تحضير بعض ستيرات الفلز المشتقة من حامض الستيرك مع فلزات الحديد والكوبلت والنيكل والنحاس والزنك وقد استخدمت هذه الستيرات كمثبتات حرارية لا PVC نتم تتخيص ستيرات الفلز المحضرة بواسطة تحليل العناصر ومطيافية الاثعة تحت الحمراء ـ كما تضمنت الدراسة ايضا استخدام مطيافية الاثعة تحت الحمراء ضمن المدى . 10. - . .9 أسم -1 لدراسة الـ PVC المحتوي على ستيرات الفلز وبالاعتماد على ثقنية الافلام الرقيقة ـ حيث درست التغيرات

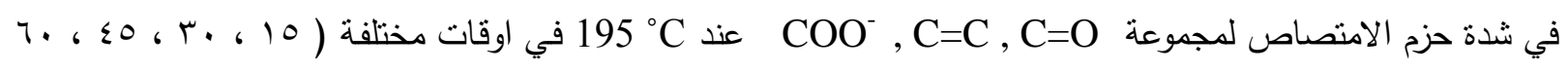

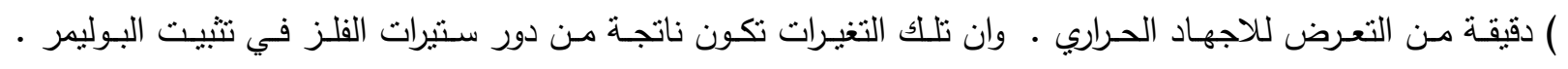
استخدمت مطيافية الاشعة المرئية وفوق البنفسجية في دراسة التفكك الحراري لا لإن المعاد ترسيبه

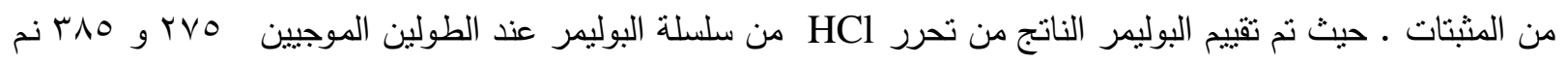
والتي تقابل تكوين ثناث وسبع اواصر مزدوجة متعاقبة على التوالي • وقد اثنارت النتائج ان سنترات الفلز وامزجتها التعاونية لها القابلية على تثبيت الـ PVC عن طريق تقليل تلك الاواصر المزدوجة المتعاقبة في البوليمر • بالاضافة الى ذلك درس الثبات الحراري لا PVC المحتوي على ستيرات الفلز وامزجتها التعاونية بواسطة تقنية التحليل الحراري الوزني , وقد حسبت لهن

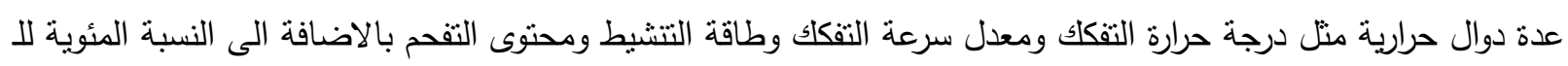
المتحرر من سلسلة البوليمر ـ وقد اثـارت النتائج بان ستيرات الفلز المحضرة تعدل على زيادة الثبات الحراري للا 